\title{
'Wie is u?' Deformalisering versus zekerheid: enkele gedachten over de wijziging van partijhoedanigheid tijdens de procedure
}

\author{
Daan Barbiersen Carla Klaassen*
}

\begin{abstract}
1 Inleiding
Voor een partij die betrokken is in een procedure is het van essentieel belang te weten wie haar wederpartij is. Dit geldt voor zowel de eiser als de gedaagde. De identiteit en de hoedanigheid van eiser en gedaagde zijn niet alleen van belang voor de mogelijke vorderingen en verweren, maar eveneens voor de reikwijdte en het effect van een rechterlijke uitspraak; deze heeft immers (slechts) gezag van gewijsde tussen de daarbij betrokken partijen ${ }^{1}$ en kan slechts ten opzichte van de partij jegens welke hierin een veroordeling is uitgesproken ten uitvoer worden gelegd. Verder kan bijvoorbeeld in beginsel alleen door en jegens een partij een rechtsmiddel tegen een uitspraak worden ingesteld. De kwestie wie precies de partijen zijn in de procedure, leidt in de praktijk echter regelmatig tot vragen. De redenen hiervoor kunnen uiteenlopend van aard zijn. Dit kan bijvoorbeeld het geval zijn vanwege (fouten in) de naamsvermelding, maar ook door rechtsopvolging dan wel wijziging van hoedanigheid gaande de procedure. Deze beschouwing gaat in op de wijziging van hoedanigheid aan de kant van de eisende partij ${ }^{2}$ gedurende de dagvaardingsprocedure. In het bijzonder wordt ingegaan op gevallen waarin de eisende partij (mede) optreedt namens of althans ten behoeve van de belangen van anderen, en er op dit punt veranderingen plaatsvinden gedurende de procedure. Men spreekt in dit verband ook wel over verschuivingen tussen de zogenoemde formele en materiele procespartij. De directe aanleiding tot deze beschouwing is
\end{abstract}

Mr. D.L. Barbiers is promovendus en docent burgerlijk recht aan de Radboud Universiteit Nijmegen. Prof. mr. C.J.M. Klaassen is hoogleraar burgerlijk recht en burgerlijk procesrecht aan de Radboud Universiteit Nijmegen.

1. Zie recentelijk HR 24 april 2020, ECLI:NL:HR:2020:810 (Leaseproces) Dexia), r.o. 2.7.1-2.7.3.

2. Hetgeen wordt opgemerkt over een verboden hoedanigheidswissel geldt echter in beginsel eveneens voor de gedaagde. Niettemin kent een hoedanigheidswissel aan die zijde ook enkele eigen aspecten. Het is immers aan eiser om te bepalen wie hij wenst aan te spreken met het oog op het gezag van gewijsde of de materiële procespartij waartegen hij een executoriale titel wenst te verkrijgen. Vgl. met het oog op een hoedanigheidswissel aan de zijde van gedaagde o.a. concl. A-G De Bock voor HR 3 april 2020, ECLI:NL:HR:2020:587 (Trafigura), onder 3.4 en de daar opgenomen verwijzingen. het Trafigura-arrest van begin april van dit jaar, waarin de Hoge Raad zich (wederom) heeft uitgelaten over deze kwestie en de daaraan te verbinden gevolgen. ${ }^{3} \mathrm{~W}_{\mathrm{ij}}$ zullen deze problematiek echter in breder verband bezien en belichten vanuit de deformaliseringstendens die meer in het algemeen reeds lange tijd op het gebied van het procesrecht valt te signaleren, en dus vanuit het spanningsveld tussen zekerheid en flexibiliteit.

\section{Wie is partij?}

Uitgangspunt is dat het antwoord op de vraag wie in een procedure als partij optreedt, wordt bepaald door het procesinleidend document; bij de dagvaardingprocedure is dus in principe bepalend het dagvaardingsexploot. Uit de rechtspraak van de Hoge Raad volgt dat in verband met de aard van dat stuk en de belangen van de wederpartij, strenge eisen moeten worden gesteld aan de duidelijkheid van de formulering van het exploot en meer in het bijzonder aan de omschrijving van de identiteit en de hoedanigheid van degene op wiens verzoek het wordt uitgebracht. Niettemin oordeelt de Hoge Raad dat het uiteindelijk een kwestie van uitleg is, waarbij de tekst van het exploot niet de enige omstandigheid is die gewicht in de schaal legt. Onder verwijzing naar de parlementaire geschiedenis heeft de Hoge Raad (eveneens) overwogen:
'De vraag in welke hoedanigheid een eisende partij optreedt, vergt uitleg van het exploot waarmee de desbe- treffende instantie wordt ingeleid. Ingevolge art. 3:59 BW zijn de artikelen 3:33 BW en 3:35 BW op deze uitleg van overeenkomstige toepassing (...).'

Nadien ingediende processtukken kunnen in dit verband eveneens relevant zijn. ${ }^{4}$ Niettemin gaat het ook bij het in

3. HR 3 april 2020, ECLI:NL:HR:2020:587 (Trafigura).

4. Zie HR 22 oktober 2004, ECLI:NL:HR:2004:AP1435, NJ 2006/202, m.nt. H.J. Snijders, JBPr 2005/5, m.nt. A. Knigge en L.C. Dufour (X/ ABN AMRO Bank), r.o. 3.4-3.6. Vgl. voor de relevantie van posterieure feiten in breder verband bijv. J.L. Smeehuijzen, noot onder HR 11 oktober 2019, ECLI:NL:HR:2019:1581, NJ 2020/197 (Fraanje/Alukon), nr. 14 e.v. 
ogenschouw nemen van latere processtukken om de vaststelling van de identiteit en de hoedanigheid waarin de eiser de procedure is begonnen en derhalve het dagvaardingsexploot heeft uitgebracht. Als zodanig vervolgt hij de procedure en gaande de procedure kan hij hierin in principe geen verandering aanbrengen, ook niet door een wijziging van eis. Men spreekt in dit verband wel van een verboden hoedanigheidswissel. De hiervoor weergegeven uitgangspunten zijn op zichzelf vrij duidelijk; de toepassing hiervan in de praktijk roept echter herhaaldelijk vragen op. De Hoge Raad heeft zich de afgelopen decennia in diverse arresten uitgelaten over de vraag of er sprake was van een (verboden) hoedanigheidswissel. In het bijzonder zijn in dit verband vragen gerezen in gevallen waarin degene op wiens naam de procedure wordt gevoerd, (mede) optreedt voor rekening of althans ten behoeve van de belangen van een ander, al dan niet van meet af aan. Hierna zullen diverse van dergelijke gevallen de revue passeren en soms worden voorzien van een (kritische) kanttekening. We ronden deze bespreking af met een tussenconclusie (par. 3.4). Vervolgens zullen we in paragraaf 4 bezien welke ruimte de rechtspraak biedt tot afwijking van het uitgangspunt dat wisselen van hoedanigheid niet is toegestaan, om van daaruit te reflecteren op de vraag of het hier gaat om wenselijke deformalisering of om ongewenst verlies van zekerheid, en onze mening geven over de wenselijke ontwikkeling op dit vlak.

\section{Wijziging van partijhoedanigheid}

\subsection{In eigen naam $\leftrightarrow$ in naam van een ander}

Een wijziging van partijhoedanigheid doet zich onder andere voor als een procespartij aanvankelijk als vertegenwoordiger optreedt en in naam van een ander een procedure aanhangig maakt, maar gedurende het geding (ook) in eigen naam een vordering instelt (of vice versa). Procederen als vertegenwoordiger oftewel namens een ander ${ }^{5}$ doet zich bijvoorbeeld voor bij procederen krachtens volmacht (art. 3:60 e.v. BW) en bij procederen (mede) namens minderjarigen (zie bijvoorbeeld art. 1:253i lid 1 of 1:337 lid $1 \mathrm{BW}$ ). In verschillende arresten heeft de Hoge Raad zich uitgelaten over wijzigingen van partijhoedanigheid in dit verband. In 1965 oordeelde de Hoge Raad dat een voogdes die in naam van een minderjarige een vordering had ingesteld, niet na aanvang van het geding als erfgename in eigen naam een vordering kon instellen. ${ }^{6}$ De Hoge Raad benadrukte daarbij dat art. $134 \mathrm{Rv}$ (oud) geen grond biedt voor een wijziging van de eiser en overwoog verder:

'dat voorts met het oog op de processuele verwikkelingen welke vervanging van de persoon des eisers mee kan

5. Tenzij anders aangegeven, doelen wij met het begrip 'vertegenwoordiger' op gevallen van directe ofwel onmiddellijke vertegenwoordiging (in navolging van Asser/Kortmann 3-III 2017/1.1). Hiervan te onderscheiden is de figuur van de zogenoemde indirecte ofwel middellijke vertegenwoordiging (zie Asser/Kortmann 3-III 2017/6). Zie over verschillende vormen van procesvertegenwoordiging ook F.E. Vermeulen, 'Vertegenwoordigingsperikelen in de civiele procedure', $M v V$ 2005, afl. 9, p. 166-170.

6. HR 14 mei 1965, ECLI:NL:HR:1965:AB4748, NJ 1965/361 (X/Y). brengen, de bevoegdheid tot zodanige vervanging zonder een wetsbepaling welke haar verleent niet kan worden aangenomen.'

De omstandigheid dat eiseres ook na de eiswijziging feitelijk dezelfde persoon bleef, achtte de Hoge Raad niet relevant. In 1993 formuleerde de Hoge Raad dit voor de procesbevoegdheid krachtens een verstrekte volmacht nog iets preciezer. Een partij die krachtens volmacht in naam van een ander een vordering wenst in te stellen, moet al in de dagvaarding de namen van de volmachtgevers vermelden, aldus de Hoge Raad. ${ }^{7}$ Nadien (in 2004) heeft de Hoge Raad in lijn hiermee geoordeeld dat een verboden wijziging van partijhoedanigheid eveneens aan de orde is wanneer een procespartij in hoger beroep of in cassatie aanvoert namens een ander op te treden, en derhalve in een andere hoedanigheid optreedt dan waarin zij haar vordering in eerste aanleg heeft ingesteld. ${ }^{8}$

\subsection{In eigen naam voor eigen rekening $\leftrightarrow$ in eigen naam voor rekening van een ander}

In geval van lastgeving is denkbaar dat de lasthebber op eigen naam, maar voor rekening van een ander - de lastgever - in rechte een vordering instelt (art. 7:414 BW).${ }^{9}$ Hoe te oordelen over het geval dat eiser aanvankelijk in eigen naam en voor eigen rekening een vordering instelt, maar gedurende het geding stelt (ook) als lasthebber voor rekening van een ander een vordering in te stellen, daarbij onverminderd procederend (slechts) in eigen naam? Is er dan (eveneens) sprake van een ontoelaatbare wijziging van partijhoedanigheid?

Een situatie die hierop lijkt, was aan de orde in een arrest van de Hoge Raad uit 2010 (Van Kessel/NationaleNederlanden). ${ }^{10}$ Daarin moest de Hoge Raad oordelen over de vraag of een partij die in de hoofdzaak in eigen naam en voor eigen rekening procedeerde, in een vrijwaringszaak enkel voor rekening van een ander kon procederen. De Hoge Raad overwoog als volgt:

'Voorts geldt weliswaar in zijn algemeenheid dat de eiser in een vrijwaringsprocedure in dezelfde hoedanigheid moet optreden als in de hoofdzaak, zodat hij niet in de vrijwaringsprocedure een vordering namens of ten behoeve van een derde kan instellen indien hij in de hoofdzaak voor zichzelf optreedt, maar deze regel lijdt in een geval als het onderhavige uitzondering.'

7. Zie HR 2 april 1993, ECLI:NL:HR:1993:ZC0919, NJ 1993/573, m.nt. D.W.F. Verkade (NVPI/Snelleman), r.o. 4.3. Zie ook HR 22 oktober 2004, ECLI:NL:HR:2004:AP1435, NJ 2006/202, m.nt. H.J. Snijders, $J B P r$ 2005/5, m.nt. A. Knigge en L.C. Dufour (X\&Y/ABN AMRO Bank), r.o. 3.4-3.6; HR 26 juni 1985, ECLI:NL:HR:1985:AC8964, NJ 1986/307, m.nt. J.M.M. Maeijer (NV Gemeenschappelijke Kernenergiecentrale Nederland/SOBI \& Stop Dodewaard), r.o. 5.1.

8. HR 12 maart 2004, ECLI:NL:HR:2004:AN8483, NJ 2009/549, m.nt. P.B. Hugenholtz (XSAALL c.s./Ad.Fab), r.o. 3.13.

9. Men spreekt dan wel van middellijke vertegenwoordiging; zie voetnoot 5 .

10. HR 26 februari 2010, ECLI:NL:HR:2010:BK4995, NJ 2011/474, m.nt. H.J. Snijders (Gebr. Van Kessel BV/Nationale-Nederlanden), r.o. 4.4.2. 
Zie over de door de Hoge Raad gemaakte uitzondering paragraaf 4.1 van deze beschouwing. Vooreerst is van belang dat de Hoge Raad vooropstelt dat een procespartij in beginsel niet namens of ten behoeve van een derde in een vrijwaringsprocedure kan optreden, als diezelfde procespartij in de hoofdzaak slechts voor zichzelf optreedt. ${ }^{11}$ In het arrest $X /$ Euretco uit 2018 - waarin het niet ging om een vrijwaringsprocedure gaat de Hoge Raad enigszins een andere kant op. In dat arrest was aan de orde dat een eiser na aanvang van het geding ook (andere) vorderingen instelde als lasthebber, dus voor rekening van een ander (maar nog altijd in eigen naam). Over de wijziging van de partijhoedanigheid van eiser overwoog de Hoge Raad: ${ }^{12}$

'De omstandigheid dat de eiser op enig moment na aanvang van de procedure stelt dat hij de vordering als lasthebber ten behoeve van de lastgever geldend maakt, brengt geen wijziging in zijn hoedanigheid als procespartij als bedoeld in onder meer HR 12 maart 2004, ECLI:NL:HR: 2004:AN8483, rov. 3.13, indien bij blijft procederen in eigen naam.

Een en ander brengt mee dat geen rechtsregel zich ertegen verzet dat de eiser die een vordering in eigen naam heeft ingesteld, op enig moment in de procedure stelt dat hij die vordering (al vanaf het begin dan wel vanaf een later tijdstip, bijvoorbeeld naar aanleiding van een overgang van de vordering op een derde) in eigen naam als lasthebber van de rechthebbende geldend maakt.' (curs. DB \& CK)

Opvallend is hier dat de Hoge Raad voor het antwoord op de vraag of sprake is van een wijziging van partijhoedanigheid beslissend acht of eiser in eigen naam blijft procederen. In het hiervoor genoemde arrest uit 2010 overwoog de Hoge Raad nog dat ook sprake is van een andere partijhoedanigheid wanneer een eiser niet voor zichzelf, maar ten behoeve van een derde een vordering instelt. Met het latere arrest $X /$ Euretco moet in ieder geval worden aangenomen dat geen wijziging van partijhoedanigheid optreedt indien een eiser die in eigen

11. Terzijde merken wij op dat de gedachte zou kunnen opkomen dat de overweging over de in beginsel verboden hoedanigheidswissel in het arrest Van Kessel/Nationale-Nederlanden is ingegeven door de omstandigheid dat het hier een vrijwaringsprocedure betrof en dit arrest derhalve 'vrijwaringsspecifiek' zou zijn. Wij menen echter dat dit niet het geval is. Immers, het lijkt niet voor de hand te liggen dat de Hoge Raad anders en met name soepeler zou oordelen over een hoedanigheidswissel in één en dezelfde procedure dan over een hoedanigheidswissel in een van de hoofdprocedure te onderscheiden vrijwaringsprocedure.

12. HR 16 november 2018, ECLI:NL:HR:2018:2112, NJ 2018/450, JBPr 2019/14, m.nt. F.J. Werners (X/Euretco), r.o. 5.2.3. Zie ook HR 21 oktober 1983, ECLI:NL:HR:1983:AG4665, NJ 1984/254, m.nt. J.M.M. Maeijer (X/Goudsblom), r.o. 3.2; HR 28 oktober 1988, ECLI:NL:HR:1988:AD0490, NJ 1989/83 (X/HBN), r.o. 3.1; M.E. Bruning, 'Partij(ver)wisselingen gedurende het burgerlijk geding; tussen ficties en werkelijkheid - Over diverse partijperikelen en koersveranderingen in de rechtspraak van de Hoge Raad', in: H.A. Groen e.a. (red.), Verandering van koers. Bundel rechtsgeleerde opstellen ter gelegenheid van het 240-jarige bestaan van het genootschap 'Door Tijd en Vlijt', Maastricht: Datawyse uitgevers 2017, p. 107-140, par. 3. naam en voor zichzelf een vordering instelt later (ook) als lasthebber in eigen naam een vordering instelt. Sterker nog: op grond van datzelfde arrest lijkt daarvoor geen eiswijziging noodzakelijk, voor zover het (inhoudelijk gezien) om dezelfde vordering blijft gaan. ${ }^{13}$

\section{3 (Anderszins) procederen in een bijzondere hoedanigheid; een drietal voorbeelden}

\subsubsection{Procederen als deelgenoot in een gemeenschap (art. 3:171 BW)}

Een (ander) voorbeeld van procederen in een bijzondere hoedanigheid biedt art. 3:171 BW. Op grond van art. 3:171 BW is iedere deelgenoot in beginsel bevoegd tot het instellen van een vordering om een uitspraak ten behoeve van de gemeenschap te verkrijgen. In de literatuur wordt verdedigd dat een procespartij die een vordering op grond van art. 3:171 BW instelt de andere deelgenoten daarbij vertegenwoordigt. ${ }^{14} \mathrm{De}$ gezamenlijke deelgenoten moeten bij een art. 3:171 BWvordering in ieder geval als materiële procespartij worden aangemerkt. De deelgenoot die een vordering op grond van art. 3:171 BW instelt, komt als formele procespartij op voor de gezamenlijke deelgenoten. ${ }^{15}$

In het arrest H/Fortis Bank (2003) oordeelt de Hoge Raad dat een procespartij die in eerste aanleg een vordering voor zichzelf instelt niet in hoger beroep een vordering op grond van art. 3:171 BW kan instellen. Dat komt volgens de Hoge Raad neer op een verboden wijziging van partijhoedanigheid. $\mathrm{Bij}$ de vordering op grond van art. 3:171 $\mathrm{BW}$ is eiser immers niet de enige materiële procespartij. ${ }^{16}$ Opvallend is dat de Hoge Raad in dit arrest de begrippen materiële en formele procespartij expliciet benadrukt. Die begrippen komen in andere arresten in de beoordeling van mogelijke wijzigingen van partijhoedanigheid niet steeds zo expliciet terug.

\subsubsection{Procederen als curator 'q.q.', 'in privé of als 'voormalig' curator}

Een ander voorbeeld van procedures waarin de vraag kan spelen of er sprake is van een (verboden) wijziging van hoedanigheid, betreffen vorderingen ingesteld door een (voormalig) curator. In de literatuur bestaat enige discussie over de vraag of een curator moet worden aangemerkt als een vertegenwoordiger van de gezamenlijke schuldeisers en/of van de failliete schuldenaar. ${ }^{17}$ Wat hiervan ook zij, in ieder geval staat vast dat een curator een specifieke partijhoedanigheid aanneemt als hij 'q.q.' voor het beheer of de vereffening van de boedel in rechte optreedt. De Hoge Raad heeft geoordeeld dat er sprake is van

13. HR 16 november 2018, ECLI:NL:HR:2018:2112, $N J$ 2018/450, JBPr 2019/14, m.nt. F.J. Werners (X/Euretco), r.o. 5.2.3-5.2.4.

14. Zie Asser/Kortmann 3-III 2017/17 en Asser/Perrick 3-V 2015/29. Vgl. tevens Asser Procesrecht/Van Schaick 2 2016/32.

15. HR 21 november 2003, ECLI:NL:HR:2003:AJ0498, NJ 2004/130 (H/Fortis Bank), r.o. 3.3.2

16. HR 21 november 2003, ECLI:NL:HR:2003:AJ0498, NJ 2004/130 (H/Fortis Bank), r.o. 3.3.2.

17. Zie hierover T.T. van Zanten, De overeenkomst in het insolventierecht (Recht en Praktijk nr. InsR3), Deventer: Kluwer 2012, par. 2.2.1.3. 
een wijziging van hoedanigheid als hij vervolgens in cassatie optreedt als 'curator in privé' of als 'voormalig curator' (als het faillissement is geëindigd) en dit niet is toegestaan, voor zover de curator niet in die hoedanigheden in eerste aanleg of hoger beroep heeft geprocedeerd. ${ }^{18}$

\subsubsection{Procederen als collectieve belangenbehartiger ofwel belangenorganisatie}

Als laatste voorbeeld van procedures waarin vragen aan de orde zijn over de hoedanigheid van de eisende partij respectievelijk de (verboden) verandering hiervan bespreken wij enkele situaties waarin een belangenorganisatie procedeert over een collectief belang. Centraal hierbij staat het Trafiguraarrest betreffende een zogenoemde 'art. 3:305a-organisatie' zoals daar aan de orde (b). Wij vangen deze paragraaf echter aan met een korte weergave van de lijn zoals deze door de Hoge Raad in zijn eerdere rechtspraak is gevolgd (a), en ronden deze af met een blik vooruit, op een procedure ingesteld door een belangenorganisatie conform het sinds 1 januari 2020 ingevolge de Wet afwikkeling massaschade in collectieve actie, ofwel de WAMCA, gewijzigde art. 3:305a BW ${ }^{19}$ (c).

\section{a. Pre-Trafigura}

Van belang zijn de arresten NVPI/Snelleman ${ }^{20}$ en Coopag/ ABN AMRO Bank. ${ }^{21}$ Het arrest NVPI/Snelleman betreft de situatie vóór de inwerkingtreding van art. 3:305a BW, dus de situatie voordat de wet expliciet voorzag in de mogelijkheid om als stichting of vereniging (zelfstandig) een collectieve actie in te stellen. Niettemin wordt door de rechter geoordeeld dat het vanwege de bijzondere omstandigheden van dat geval gewettigd is te aanvaarden dat een belangenbehartiger zoals de Nederlandse Vereniging van Producenten en Importeurs van beeld- en geluidsdragers (NVPI) de bevoegdheid toekomt om bij de burgerlijke rechter een vordering in te stellen ter zake van een aantasting van belangen waarvan zij blijkens haar doelomschrijving de behartiging op zich heeft genomen. ${ }^{22}$ Met andere woorden: de NVPI is ontvankelijk in haar collectieve actie ten behoeve van haar leden. Echter: in hoger beroep heeft de NVPI bij pleidooi een aantal volmachten overgelegd en akte gevraagd van enerzijds de omstandigheid dat zij in dit geding tevens optreedt als vertegenwoordiger van een aantal uitvoerende kunstenaars en anderzijds de omstandigheid dat zij optreedt als zaakwaarnemer van uitvoerende kunstenaars. Gelet op het onderscheid dat de NVPI maakt tussen het optreden als vertegenwoordiger dan wel zaakwaarnemer, lijkt in dit laatste geval te worden uitgegaan van een optreden in

18. HR 29 juni 2012, ECLI:NL:HR:2012:BU5630, NJ 2012/424 (Yukos), r.o. 4.1.3.

19. Zie voor een weergave van de hoofdlijnen van deze regeling bijv. C.J.M. Klaassen, 'De Wet afwikkeling massaschade in collectieve actie: eindelijk werkelijkheid, nu nog gaan werken', TCR 2019, afl. 4, p. 145-152.

20. HR 2 april 1993, ECLI:NL:HR:1993:ZC0919, NJ 1993/573, m.nt. D.W.F. Verkade (NVPI/Snelleman), r.o. 4.3.

21. HR 2 december 1994, ECLI:NL:HR:1994:ZC1562, NJ 1996/246, m.nt. D.W.F. Verkade (Coopag/ABN AMRO Bank), r.o. 5.2.

22. Deze omstandigheden zijn voor de onderhavige beschouwing niet relevant en worden daarom onvermeld gelaten. eigen naam voor rekening van de kunstenaars. ${ }^{23}$ De Hoge Raad volgt het hof in diens oordeel dat noch de ene, noch de andere wijziging van hoedanigheid in de loop van een procedure is toegestaan:

'Het hof heeft echter met zijn hiervoor omschreven oordeel tot uitdrukking gebracht dat een eisende partij die niet reeds bij dagvaarding heeft gesteld (mede) op te treden als gevolmachtigde van een met name genoemde volmachtgever, niet hangende de procedure die hoedanigheid alsnog kan aannemen door op de voet van art. $134 \mathrm{Rv}$ haar eis te veranderen. Dit oordeel is juist, $n u$ in het onderhavige geval de volmachtgevers niet behoorden tot de groep van niet met name genoemde belanghebbenden - de leden van de vereniging - te wier behoeve de vordering is ingesteld. De eisende partij die in de loop van een procedure alsnog mede als gevolmachtigde van een derde wenst op te treden, zal zich in die hoedanigheid wèl in de procedure kunnen voegen.' (curs. DB \& CK)

Voorts volgt ten aanzien van het beroep op zaakwaarneming een vergelijkbare overweging van de Hoge Raad wat betreft de ontoelaatbaarheid van een hoedanigheidsverandering c.q. - uitbreiding.

In Vereniging Coopag/ABN AMRO Bank oordeelde de Hoge Raad in soortgelijke zin in het kader van een collectieve actie betreffende beleggingsschade uit hoofde van prospectusaansprakelijkheid (zij het dat feitelijk bezien het resultaat voor de eisers uiteindelijk gunstiger uitpakte). Het ging hier om de ontvankelijkheid van een belangenbehartiger in de zin van art. 3:305a BW (oud) (zoals dat gold van juli 1994 tot 2020), die na aanvang van de procedure stelde tevens op te treden voor beleggers die hun vordering ná het uitbrengen van de dagvaarding aan hem hebben gecedeerd. Het hof oordeelt dit niet toelaatbaar, ervan uitgaande dat Vereniging Coopag (slechts) optrad als lasthebber op eigen naam, uit hoofde van vorderingen die door de beleggers ter incasso aan haar waren gecedeerd. De Hoge Raad oordeelt echter dat Coopag als belangenbehartiger procesbevoegd is op grond van art. 3:305a BW (oud). Dit leidt tevens tot een ander oordeel wat betreft de ontvankelijkheid ter zake van later aan haar ter incasso gecedeerde vorderingen:

'Zoals volgt uit hetgeen onder 5.1 is overwogen was de Vereniging [op grond van art. 3:305a BW (oud); DB \& $\mathrm{CK}$ ] bevoegd in rechte op te treden ter behartiging van de belangen van houders van obligaties Coopag ook voor zover zij hun vorderingen - nog - niet aan de Vereniging hadden gecedeerd. Uitgaande van deze bevoegdheid valt niet in te zien waarom de Vereniging niet ook de belangen van deze obligatiehouders zou kunnen behartigen ter zake van bun ter incasso gecedeerde vorderingen tot schade-

23. Zie art. 6:198 e.v. BW, waaronder m.n. art. 6:201 BW. Zie tevens voetnoot 5 . 
vergoeding, ongeacht of deze cessie terstond of enige tijd later had plaatsgevonden.' (curs. DB \& CK)

Geconcludeerd kan dus worden dat in het geval (latere) lastgevers, volmachtgevers of degenen wier zaken worden waargenomen (al dan niet als directe vertegenwoordiger ${ }^{24}$ ) reeds tot de groep behoren waarvoor een belangenbehartiger uit eigen hoofde bevoegd opkomt in een collectieve actie, volgens de Hoge Raad van een verboden hoedanigheidsverandering geen sprake is en de belangenbehartiger ook hun belangen in de procedure kan vertegenwoordigen. Indien hun belangen echter niet behoren tot de belangen ter zake waarvan de belangenbehartiger reeds bevoegd was, kan lastgeving, volmachtverlening of zaakwaarneming er volgens de besproken rechtspraak niet toe leiden dat de eiser ter zake gaande de procedure, door wijziging van de eis, alsnog bevoegd wordt.

\section{b. Het Trafigura-arrest}

In de Trafigura-zaak die heeft geleid tot het arrest van de Hoge Raad van 3 april 2020, is Trafigura in rechte betrokken door Stichting Union des Victimes de Déchets Toxiques D’Abidjan et Banlieues (hierna: de Stichting) betreffende de illegale storting van afvalstoffen in en rond Abidjan (Ivoorkust). De Stichting heeft in de procesinleidende dagvaarding omtrent haar hoedanigheid onder andere gesteld 110.937 Ivoriaanse slachtoffers te vertegenwoordigen en van hen een volmacht te hebben verkregen; zij verwijst naar een aan Trafigura betekende lijst met slachtoffers. Vervolgens heeft de Stichting haar eis gewijzigd in een primaire en een subsidiaire eis, waarbij zij stelt ter zake van de primaire eis op te treden als claimstichting in de zin van art. 3:305a BW (thans art. 3:305a BW (oud)), en ter zake van de subsidiaire eis (enkel) met volmacht van de slachtoffers te procederen. Het hof beschouwt deze wijziging van eis als een verandering van hoedanigheid, die niet geoorloofd is en derhalve buiten beschouwing moet worden gelaten. De Hoge Raad volgt het hof in diens oordeel dat sprake is van een wijziging van partijhoedanigheid en overweegt:

'Indien een stichting als vertegenwoordiger van gedupeerden een vordering instelt en vervolgens haar eis aldus wijzigt dat zij een vordering instelt op de voet van art. 3:305a $\mathrm{BW}$, impliceert die eiswijziging (...) een wijziging van de hoedanigheid waarin de stichting in het geding optreedt.'

Niettemin oordeelt de Hoge Raad dat in de onderhavige zaak, uitgaande van de in cassatie vaststaande of althans veronderstellenderwijs aangenomen omstandigheden, een uitzondering moet worden gemaakt op het verbod tot wijziging van partijhoedanigheid. Alvorens daarop nader in te gaan (zie par. 4.1), eerst enkele opmerkingen over het door de Hoge Raad gehanteerde uitgangspunt - dat sprake is van een (in beginsel verboden) wijziging van hoedanigheid - teneinde de reikwijdte hiervan beter te doorgronden en derhalve tevens het

24. Zie voetnoot 5 en 23 terrein waarbinnen de discussie over de wenselijkheid van uitzonderingen zich afspeelt.

De Hoge Raad refereert aan de gronden zoals uiteengezet door A-G De Bock. ${ }^{25}$ De Bock concludeert dat een 305arechtspersoon zelfstandig, voor zichzelf optreedt als procespartij alsmede dat een dergelijke rechtspersoon weliswaar optreedt ter behartiging van de belangen van anderen, maar dit niet betekent dat hij in een procedure slechts als formele procespartij kan worden aangemerkt, dus slechts als degene op wiens naam de procedure wordt gevoerd en die de benodigde beslissingen in de procedure neemt. De 305a-organisatie beschouwt zij als zowel de formele als de materiële procespartij. ${ }^{26}$ De belanghebbenden voor wie de belangenorganisatie optreedt, zijn in de door de 305a-organisatie gevoerde procedure derden, en geen partij, noch in formele, noch in materiële zin (en voor hen heeft de uitspraak dan ook geen gezag van gewijsde). Ervan uitgaande dat de Stichting de inleidende dagvaarding uitsluitend in haar hoedanigheid van vertegenwoordiger van de slachtoffers heeft uitgebracht, ${ }^{27}$ dus als formele procespartij, volgt daaruit dat het oordeel van het hof, dat sprake is van een (niet-geoorloofde) hoedanigheidswisseling van de Stichting, geen blijk geeft van een onjuiste rechtsopvatting, aldus de A-G. Dat de Stichting ook na de eiswijziging de formele procespartij blijft, maakt dit niet anders, zo voegt De Bock toe, onder verwijzing naar het hiervoor (in par. 3.1) besproken arrest uit $1965 .{ }^{28}$ Dit betoog ligt in het verlengde van de eerdere opmerking van de A-G, dat een wijziging van partijhoedanigheid plaatsvindt als een formele procespartij óók materiële procespartij wordt, of als een formele én materiële procespartij enkel formele procespartij wordt. ${ }^{29}$ De Hoge Raad sluit zich, zoals vermeld, kennelijk aan bij de redenering van zijn A-G.

\section{Twee kanttekeningen}

De vraag is hoe dit oordeel van de Hoge Raad zich verhoudt tot zijn eerdere rechtspraak. Wij plaatsen een tweetal kanttekeningen.

Allereerst is niet helemaal duidelijk in welke hoedanigheid de Stichting aanvankelijk optrad: als gevolmachtigde, dus namens en voor rekening van een ander, dan wel enkel voor rekening van een ander (als lasthebber), maar op eigen naam. Uit het arrest van het hof en de aangehaalde processtukken lijkt te volgen dat de Stichting aanvankelijk vorderingen instelde op grond van volmacht, maar, zoals vermeld, geheel duidelijk is dat niet. Het hof spreekt van optreden als '(directe

25. R.o. 3.2, waarin wordt verwezen naar de conclusie onder 4.10-4.14. Zie tevens onder 4.17 .

26. Zie concl. A-G De Bock onder 3.2 voor de nadere duiding van de begrippen formele en materiële procespartij, met verwijzing naar verdere literatuur.

27. Hierover is enige twijfel mogelijk. Zie concl. A-G De Bock onder 4.28-4.31, alsook de (eerste) kanttekening die wij hierna plaatsen.

28. Concl. onder 4.17.

29. Zie concl. A-G De Bock bij HR 3 april 2020, ECLI:NL:HR:2020:587 (Trafigura), onder 3.7 . 
en/of indirecte) vertegenwoordiger'. ${ }^{30}$ De Hoge Raad rept enkel van 'vertegenwoordiger', waarmee veelal wordt gedoeld op directe ofwel onmiddellijke vertegenwoordiging, en derhalve handelen op naam en voor rekening van een derde. ${ }^{31}$ Gelet op voormelde onduidelijkheid is echter niet klip-en-klaar of de Hoge Raad onder vertegenwoordiger tevens een lasthebber verstaat die in eigen naam procedeert, en dus optreedt als indirecte ofwel middellijke vertegenwoordiger, zoals aan de orde was in het hiervoor genoemde arrest X/Euretco uit 2018. Stel nu dat vast zou staan dat eiseres aanvankelijk in eigen naam op grond van lastgeving een vordering instelde, zou dan ook sprake zijn geweest van een wijziging van partijhoedanigheid? Daarover is twijfel mogelijk. ${ }^{32}$ In zowel de hoedanigheid van 305a-belangenbehartiger als die van indirecte ofwel middellijke vertegenwoordiger procedeert een eiser in eigen naam, ${ }^{33}$ en dat gegeven lijkt de Hoge Raad in het arrest X/Euretco beslissend te achten voor de vraag of sprake is van een wijziging van partijhoedanigheid. ${ }^{34}$ Tegelijkertijd verwijst de Hoge Raad in het Trafigura-arrest instemmend naar passages uit de conclusie van A-G De Bock waarin wordt aangenomen dat een belangenbehartiger in de zin van art. 3:305a BW zowel materiële als formele procespartij is, ${ }^{35}$ daarbij voortbouwend op haar eerdere standpunt, dat een wijziging van partijhoedanigheid plaatsvindt als een formele procespartij óók materiële procespartij wordt, of als een formele én materiële procespartij enkel formele procespartij wordt. ${ }^{36}$ Volgens deze redenering is echter ook sprake van een (verboden) wijziging van partijhoedanigheid bij een lasthebber die optreedt in eigen naam en vervolgens de hoedanigheid aanneemt van een belangenbehartiger in de zin van art. 3:305a BW (of andersom). ${ }^{37}$ Deze lasthebber wordt dan immers ook van slechts formele procespartij

30. Hof Amsterdam 16 oktober 2018, ECLI:NL:GHAMS:2018:3707, $J B P r$ 2019/6, m.nt. D.L. Barbiers, r.o. 3.17; zie tevens de weergave door de Hoge Raad, r.o. 2.25 en concl. A-G De Bock onder 4.28-4.31.

31. HR 3 april 2020, ECLI:NL:HR:2020:587 (Trafigura), r.o. 3.2. Zie tevens voetnoot 5 .

32. Zie hierover reeds de noot van D.L. Barbiers bij Hof Amsterdam 16 oktober 2018, ECLI:NL:GHAMS:2018:3707, JBPr 2019/6, p. 96.

33. Zie voor art. 3:305a BW, HR 7 november 1997, ECLI:NL:HR: 1997:ZC2483, NJ 1998/268, m.nt. J.M.M. Maeijer (Philips/VEB c.s.), r.o. 3.3.3.

34. Zie HR 16 november 2018, ECLI:NL:HR:2018:2112, NJ 2018/450, $J B P r$ 2019/14, m.nt. F.J. Werners (X/Euretco), r.o. 5.2.3.

35. HR 3 april 2020, ECLI:NL:HR:2020:587 (Trafigura), r.o. 3.2.

36. Zie concl. A-G De Bock bij HR 3 april 2020, ECLI:NL:HR:2020:587 (Trafigura), onder 3.7.

37. Vgl. concl. A-G De Bock bij HR 3 april 2020, ECLI:NL:HR:2020:587 (Trafigura), onder 3.3, 3.7 en 4.29 . zowel formele als materiële procespartij. ${ }^{38}$ Die conclusie verhoudt zich evenwel slecht tot de hiervoor gememoreerde overwegingen uit het arrest $X /$ Euretco.

Onze tweede kanttekening betreft de verhouding tussen het oordeel van de Hoge Raad in Trafigura en diens oordeel in de arresten NVPI/Snelleman en Coopag/ABN AMRO Bank. In NVPI/Snelleman en Coopag/ABN AMRO Bank oordeelde de Hoge Raad immers dat indien lastgevers of volmachtgevers reeds tot de groep behoren waarvoor een belangenbehartiger in collectieve actie opkomt, van een verboden hoedanigheidswisseling geen sprake is. In Trafigura overweegt de Hoge Raad dat een vertegenwoordiger die (ook) belangenbehartiger wordt (in beginsel) op een ongeoorloofde wijze zijn partijhoedanigheid wijzigt. Volgt men de (kennelijke ${ }^{39}$ ) opvatting van de Hoge Raad dat een belangenbehartiger in de zin van art. 3:305a BW materiële en formele procespartij is, en neemt men ook aan dat om die reden een wijziging van partijhoedanigheid optreedt als een vertegenwoordiger (die (slechts) formele procespartij is ${ }^{40}$ ) belangenbehartiger (en daarmee formele én materiële procespartij) wordt, dan is het oordeel in NVPI/ Snelleman en Coopag/ABN AMRO Bank opvallend. Ook in die arresten zou volgens deze redenering immers een wijziging van partijhoedanigheid hebben plaatsgevonden: van belangenbehartiger naar belangenbehartiger én (middellijk) vertegenwoordiger.

c. De belangenorganisatie onder de WAMCA

In de conclusie bij het Trafigura-arrest maakt de A-G tevens een uitstapje naar de per 1 januari 2020 in werking getreden

38. In de literatuur wordt over het algemeen aangenomen dat een lasthebber enkel een formele procespartij is. Niettemin kan de uitkomst van een procedure waarin een lasthebber op eigen naam optreedt, ook consequenties voor die lasthebber hebben. Verder lijkt vast te staan dat een uitkomst van een procedure gezag van gewijsde heeft voor de lastgever, indien een lasthebber voor hem in eigen of zijn naam opkomt. De lastgever is in die opvatting immers als materiële procespartij gebonden op grond van art. 236 lid $1 \mathrm{Rv}$. Een tegengestelde opvatting zou betekenen dat de lastgever opnieuw over zijn of haar vordering kan procederen, zonder daarbij de beperkingen van het gezag van gewijsde te ondervinden. Zie HR 24 april 1992, ECLI:NL:HR:1992:ZC0586, NJ 1992/461 (Carreau Gaschereau/Sunresorts), r.o. 3.2 (in de context van art. 3:171 BW). Zie over dit alles H.J. Snijders, C.J.M. Klaassen \& G.J. Meijer, Nederlands burgerlijk procesrecht, Deventer: Wolters Kluwer 2017/65 en 67; D.F.H. Rijkers, 'Procederen in hoedanigheid: enkele procesrechtelijke gevolgen van partijvertegenwoordiging op grond van volmacht en lastgeving in eigen naam', $J B P r$ 2013, afl. 3, p. 288-296, p. 294-295 (met verwijzingen naar verdere literatuur in voetnoot 30 en 31); J.W.A. Biemans, Rechtsgevolgen van stille cessie (Onderneming en Recht nr. 65), Deventer: Kluwer 2011, par. 3.5.2.1, 3.5.2.3, 3.5.11.3 en 3.5.11.4; Vermeulen 2005, p. 169-170. Vgl. ook concl. A-G De Bock bij HR 3 april 2020, ECLI:NL:HR:2020:587 (Trafigura), onder 3.3, 3.7, 4.17 en 4.29-4.30; concl. A-G Asser bij HR 20 oktober 1995, ECLI:NL:HR:1995:ZC1848, NJ 1996/218 (Bouw-en Houtbond FNV) Weltec), onder 2.15; concl. A-G Timmerman bij HR 16 november 2018, ECLI:NL:HR:2018:2112, NJ 2018/450, JBPr 2019/14, m.nt. F.J. Werners (X/Euretco), onder 3.46; HR 26 februari 2010, ECLI:NL:HR:2010:BK4995, NJ 2011/474, m.nt. H.J. Snijders (Gebr. Van Kessel BV/Nationale-Nederlanden), r.o. 4.4.2.

39. De Hoge Raad verwijst instemmend naar de conclusie van A-G De Bock. Zie HR 3 april 2020, ECLI:NL:HR:2020:587 (Trafigura), r.o. 3.2 .

40. Zie voetnoot 38 . 
WAMCA. Gerefereerd wordt aan de ingevolge deze wet in art. $1018 \mathrm{f}$ lid $1 \mathrm{Rv}$ neergelegde opt-outmogelijkheid. Ten anzien van belanghebbenden die geen gebruik maken van deze opt-outmogelijkheid ${ }^{41}$ heeft de rechterlijke uitspraak in een door een 305a-organisatie geëntameerde procedure gezag van gewijsde. A-G De Bock merkt op dat dit niet betekent dat deze belanghebbenden onder de WAMCA wél zouden moeten worden aangemerkt als materiële procespartij. De Hoge Raad sluit zich ook in dit opzicht aan bij de visie van zijn A-G, die wij eveneens onderschrijven. ${ }^{42}$ De WAMCA verandert immers niets aan de omstandigheid dat een 305a-organisatie weliswaar de belangen van anderen behartigt, maar in rechte optreedt voor zichzelf.

Een andere vraag is of een belangenorganisatie die niet aan de in het kader van de WAMCA aangescherpte ontvankelijkheidsvereisten blijkt te voldoen, in eigen naam kan voortprocederen als lasthebber van dezelfde belanghebbenden. ${ }^{43}$ Hoewel dit in het licht van het arrest X/Euretco mogelijk lijkt, lijkt dit tegen de achtergrond van het Trafigura-arrest in principe een verboden hoedanigheidswissel. ${ }^{44}$

\subsection{Tussenconclusie}

Op grond van de hiervoor besproken rechtspraak concluderen wij dat een wijziging van partijhoedanigheid in beginsel niet is toegestaan. De Hoge Raad motiveert deze regel in het Trafigu$r a$-arrest met een verwijzing naar de eisen van een goede procesorde. De Hoge Raad lijkt de beantwoording van de vraag óf in een voorkomend geval sprake is van een wijziging van partijhoedanigheid evenwel niet altijd op dezelfde wijze te benaderen en te motiveren. In sommige gevallen kent de Hoge Raad (impliciet) betekenis toe aan de begrippen materiële en formele procespartij en acht hij verschuivingen op dit vlak bepalend ${ }^{45}$ in andere gevallen benadrukt de Hoge Raad dat doorslaggevend is of een eiser in eigen naam blijft procederen en lijkt het materiële procesbelang niet van betekenis. ${ }^{46}$

Echter, ook als een wijziging van partijhoedanigheid aanwezig wordt geoordeeld, hoeft dit niet altijd verboden te zijn. Hierna bespreken wij enkele gevallen waarin een wijziging van

41. Overigens kent de WAMCA in art. 1018h lid 5 Rv nog een tweede optoutmogelijkheid. Deze ziet evenwel op de rechterlijke goedkeuring van een schikking; niet op een rechterlijke uitspraak over de kwesties die het onderwerp van geschil zijn, zoals hier aan de orde.

42. Concl. A-G onder 4.15 en 4.16, en Hoge Raad, r.o. 3.2 slot.

43. De omgekeerde situatie, dat de eiser aanvankelijk optreedt als lasthebber in eigen naam, en vervolgens stelt op te treden als 305a-organisatie, lijkt zich vanwege de aangescherpte ontvankelijkheidsvereisten onder de WAMCA niet snel te zullen voordoen. In elk geval menen wij dat de inrichting van de WAMCA-procedure ertoe zal leiden dat een dergelijke hoedanigheidswissel (in principe) in strijd met de goede procesorde moet worden geacht.

44. Dat voortprocederen als (direct) vertegenwoordiger, op grond van volmacht, een (in principe) verboden hoedanigheidsverandering betreft, staat in het licht van de rechtspraak buiten kijf.

45. Zie HR 3 april 2020, ECLI:NL:HR:2020:587 (Trafigura), r.o. 3.2 (indirect door verwijzing naar de conclusie van A-G De Bock) en HR 21 november 2003, ECLI:NL:HR:2003:AJ0498, NJ 2004/130 (H/Fortis Bank), r.o. 3.3.2.

46. Zie bijv. HR 16 november 2018, ECLI:NL:HR:2018:2112, NJ 2018/450, JBPr 2019/14, m.nt. F.J. Werners (X/Euretco), r.o. 5.2.3. partijhoedanigheid bij wijze van uitzondering tóch toelaatbaar is geoordeeld, en geven wij daarop onze visie.

\section{Uitzonderingen op een verboden wijziging van partijhoedanigheid}

\subsection{Wanneer en waarom? De rechtspraak}

De Hoge Raad oordeelt in het Trafigura-arrest onder de daar (deels veronderstellenderwijs) aangenomen omstandigheden dat een uitzondering op het verbod tot het tussentijds wijzigen van de partijhoedanigheid op zijn plaats is. Dit is echter niet de eerste keer dat de Hoge Raad oordeelt dat er wél sprake is van een verandering van hoedanigheid, maar dit niet ontoelaatbaar acht. ${ }^{47}$ In vrijwaringszaak Van Kessel/NationaleNederlanden (par. 3.2) nam de Hoge Raad een uitzondering aan omdat het optreden van Van Kessel als lasthebber (van verzekeraar Allianz, van wie deze een uitkering had ontvangen), in plaats van voor zichzelf, er niet aan afdeed dat het in de procedure tegenover Nationale-Nederlanden nog steeds ging om dezelfde centrale vraag, namelijk of Van Kessel dekking kon ontlenen aan de bij Nationale-Nederlanden gesloten verzekering. Voor de behandeling en beoordeling hiervan maakt het geen verschil of Van Kessel deze vordering ten behoeve van zichzelf dan wel (na overgang van de vordering op gesubrogeerde Allianz) ten behoeve van Allianz geldend maakt. Overwogen wordt:

'Het voorgaande leidt tot het praktische resultaat dat de (vrijwarings)procedure van een verzekerde tegen de verzekeraar kan worden voortgezet ook nadat de verzekerde een uitkering heeft verkregen van een andere verzekeraar op wie de vordering overgaat, omdat de verzekerde de procedure dan als lasthebber kan voortzetten ten behoeve van die andere verzekeraar als materiële procespartij, ongeacht het tijdstip waarop die uitkering en overgang hebben plaatsgevonden. ${ }^{48}$

In het Trafigura-arrest motiveert de Hoge Raad het buiten toepassing laten van het verbod op het wijzigen van partijhoedanigheid met een verwijzing naar de 'bijzondere omstandigheden' die in dat geval aan de orde waren. De Hoge Raad wijst allereerst op de omstandigheid dat de Stichting al in een zeer

47. Hiervoor (par. 3.3.3 onder a) zagen we dat de Hoge Raad in de arresten NVPI/Snelleman en Coopag/ABN AMRO Bank vrij soepel omgaat met de situatie waarin een belangenbehartiger in de zin van art. 3:305a BW na aanvang van de procedure ook een vordering instelt als lasthebber of gevolmachtigde. Dat zou mogelijk ook kunnen worden gezien als een uitzondering op het verbod op het wijzigen van een partijhoedanigheid, omdat in dat geval toch sprake is van een formele en materiële procespartij (belangenbehartiger) die ook enkel formele procespartij wordt (lasthebber of gevolmachtigde). Niettemin plaatst de Hoge Raad dit daar niet in de sleutel van een uitzondering op de regel (HR 2 april 1993, ECLI:NL:HR:1993:ZC0919, NJ 1993/573, m.nt. D.W.F. Verkade (NVPI/Snelleman), r.o. 4.3 en HR 2 december 1994, ECLI:NL:HR:1994:ZC1562, NJ 1996/246, m.nt. D.W.F. Verkade (Coopag/ABN AMRO Bank), r.o. 5.2). Zie ook par. 5.

48. HR 26 februari 2010, ECLI:NL:HR:2010:BK4995, NJ 2011/474, m.nt. H.J. Snijders (Gebr. Van Kessel BV/Nationale-Nederlanden), r.o. 4.4.2. Vgl. Biemans 2011, par. 3.5.4.3. 
vroeg stadium in de procedure in eerste aanleg haar eis heeft gewijzigd, namelijk nog voordat Trafigura voor antwoord had geconcludeerd en nog voordat een (regie)zitting was gehouden. Verder refereert de Hoge Raad aan (1) het in cassatie niet bestreden oordeel van het hof, dat Trafigura blijkens een door haar advocaat aan de rechtbank gezonden brief - waarin werd verzocht om een regiezitting - rekening hield met de omstandigheid dat de Stichting ook in de hoedanigheid van claimstichting in de zin van art. 3:305a BW (oud) beoogde op te treden, en (2) de in cassatie veronderstellenderwijs aangenomen omstandigheid dat Trafigura door de wijziging van partijhoedanigheid van de Stichting niet in haar processuele belangen wordt geschaad. ${ }^{49}$ Deze laatste omstandigheid sluit aan bij de motivering in het arrest Van Kessel/NationaleNederlanden.

\subsection{Hoever te gaan? Gewenste deformalisering of ongewenst verlies van zekerheid?}

De door de Hoge Raad toegestane uitzonderingen op de in beginsel verboden verandering van proceshoedanigheid sluiten aan bij de deformaliseringstendens die in het burgerlijk procesrecht reeds vele decennia gaande is. Wat betreft het recentere verleden kan bijvoorbeeld worden gewezen op de herziening van het burgerlijk procesrecht in 2002, waardoor (onder andere) herstel van kennelijke fouten in een uitspraak eenvoudiger is geworden. ${ }^{50}$ Maar ook de Hoge Raad heeft de deformaliseringshandschoen ruimschoots opgepakt. In dit verband kan worden gedacht aan de uitzonderingen op de tweeconclusieregel, waardoor soepeler wordt omgegaan met de in beginsel strakke regel' van art. 347 lid $1 \mathrm{Rv},{ }^{51}$ maar tevens aan de ruimte voor wijziging van een partijaanduiding in een volgende instantie, ${ }^{52}$ alsook aan de coulance bij fouten bij het uitbrengen van een dagvaarding. ${ }^{53}$ Deformalisering óók op het gebied van de verandering van partijhoedanigheid past hierbij. Men kan dit tevens plaatsen in de sleutel van het beginsel van de zogenoemde 'interne toegankelijkheid' van het proces: de processuele route tot effectuering van het recht dient toegankelijk te zijn en onnodige of althans in verhouding tot hun

49. Zie r.o. 3.3.

50. Zie art. $31 \mathrm{Rv}$.

51. HR 22 december 2017, ECLI:NL:HR:2017:3238, NJ 2018/31 (A/X), r.o. 3.3.2-3.3.3; HR 19 juni 2009, ECLI:NL:HR:2009:BI8771, NJ 2010/154, m.nt. H.J. Snijders (Wertenbroek q.q./X), r.o. 2.4.1-2.5; HR 20 juni 2008, ECLI:NL:HR:2008:BC4959, NJ 2009/21, m.nt. J.M.M. Maeijer en H.J. Snijders (X/NOM), r.o. 4.2.1-4.2.5.

52. HR 13 december 2013, ECLI:NL:HR:2013:1881, NJ 2015/307 (Montis Design $/ X$ ), r.o. 5.4-5.6; HR 11 september 2009, ECLI:NL:HR: 2009:BI4198, NJ 2010/415, m.nt. H.J. Snijders (Stichting AWH en Viveste $(X)$, r.o. 5.5. Voor een helder overzicht van de rechtspraak van de Hoge Raad over wijziging van een partijaanduiding in een volgende instantie, zie concl. A-G Van Peursem bij HR 22 juni 2018, ECLI:NL:HR:2018:982, NJ 2019/422, m.nt. A.I.M. van Mierlo $(X / Y)$, onder 2.15-2.20.

53. HR 6 november 2009, ECLI:NL:HR:2009:BJ3043, NJ 2010/580, m.nt. H.J. Snijders $(X / Y)$, r.o. 3.3-3.4. Zie echter ook HR 24 juni 2016, ECLI:NL:HR:2016:1311, NJ 2018/70, m.nt. H.J. Snijders $(X / Y)$, r.o. 3.3.2-3.3.3. Voor een helder overzicht van de rechtspraak van de Hoge Raad over fouten bij het uitbrengen van een dagvaarding, zie concl. A-G Van Peursem bij HR 22 juni 2018, ECLI:NL:HR:2018:982, NJ 2019/422, m.nt. A.I.M. van Mierlo $(X / Y)$, onder 2.15-2.20. belang onredelijk bezwarende formalismen moeten worden geëlimineerd. De interne toegankelijkheid dient, als daarvoor geen goede reden bestaat, niet te worden belemmerd door formalistische barrières. Dergelijke barrières ofwel procesregels dienen zo nodig terzijde te worden gesteld, althans dienen in een voorliggend geval buiten toepassing te worden gelaten als zij eraan in de weg staan dat het recht zijn loop heeft, terwijl de verwezenlijking van de ratio van de desbetreffende regel niet in het geding is c.q. de balans tussen het belang dat de regel beoogt te dienen en het belang dat hierdoor in het gedrang komt onverkorte toepassing van de regel niet rechtvaardigt. ${ }^{54}$ Zoals zowel het Trafigura-arrest als de overige hiervoor besproken arresten illustreren, kunnen aan de kant van de 'nieuwe' eiser met name de eisen van een doelmatige procesvoering c.q. de proceseconomie gewicht in de schaal leggen. Immers (zoals door de Hoge Raad ook een enkele maal is aangegeven), door middel van (voeging ${ }^{55}$ of) tussenkomst kan hetzelfde resultaat worden bereikt als met de verandering van proceshoedanigheid wordt beoogd: als eisende partij meedoen in een aanhangige procedure. Het wijzigen van de partijhoedanigheid is echter een (enigszins) snellere, eenvoudigere en ook goedkopere weg om dit te bewerkstelligen. Dit belang aan de kant van de eiser dient te worden afgezet tegen allereerst het verdedigingsbelang aan de kant van de gedaagde partij: voor haar is van belang dat helder is tegen welke vordering en welke wederpartij zij haar verweer dient te richten én dat de procedure (nog) voldoende gelegenheid biedt om hiertegen adequaat verweer te voeren. Om die reden dient voorop te worden gesteld dat de wet niet voorziet in een hoedanigheidswissel gaande de procedure en dit derhalve in principe niet toelaatbaar is. ${ }^{56}$ Indien echter de gedaagde door een wijziging van partijhoedanigheid niet wordt bemoeilijkt in zijn verweer, bestaat tegen een dergelijke wijziging in beginsel geen bezwaar en prevaleert het belang aan de zijde van de eisende partij om zo nodig op eenvoudige wijze van hoedanigheid te kunnen veranderen en recht te doen aan de (materiële) werkelijkheid. Van belang is dat het gezag van gewijsde zich uitstrekt tot de materiële procespartijen en dat de uitspraak een executoriale titel oplevert voor of tegen de materiële procespartij. ${ }^{57}$ Tegen de achtergrond van het verdedigingsbelang is begrijpelijk dat in het arrest $V$ an Kessel/Nationale-Nederlanden door de Hoge Raad niet relevant werd gevonden op welk moment Nationa-

54. Zie reeds Snijders, Klaassen \& Meijer 2017/38, waarnaar ook word verwezen in de conclusie van A-G De Bock voor het Trafigura-arrest, onder 4.25 .

55. Art. 217-219a Rv. In NVPI/Snelleman (NJ 1993/573) vermeldt de Hoge Raad de mogelijkheid van voeging. Vgl. over de mogelijkheid tot voeging tevens recentelijk HR 3 april 2020, ECLI:NL:HR:2020:601 (AT Osborne/Sona), r.o. 3.1-3.3. Gelet op HR 28 maart 2014, ECLI:HR:NL:2014:768, NJ 2015/206, m.nt. H.B. Krans (Fair c.s.) Thuiskopie), r.o. 4.1.2, 4.2.2 en 5.3, lijkt in de door ons besproken situaties echter tussenkomen de aangewezen route. Vgl. voor een vrij recent voorbeeld van tussenkomen als vertegenwoordiger Hof Arnhem-Leeuwarden 5 februari 2019, ECLI:NL:GHARL:2019:1032, r.o. 3.1-3.10.

56. Vgl. expliciet HR 14 mei 1965, ECLI:NL:HR:1965:AB4748, NJ $1965 / 361(X / Y)$.

57. Zie voetnoot 38. Zie in het bijzonder ook Biemans 2011, par. 3.5.2.1, 3.5.2.3, 3.5.11.3 en 3.5.11.4; concl. A-G De Bock bij HR 3 april 2020, ECLI:NL:HR:2020:587 (Trafigura), onder 4.12; Rijkers 2013, p. 295. 
le-Nederlanden op de hoogte geraakte van de omstandigheid dat Van Kessel optrad voor rekening van Allianz: dit veranderde kennelijk niets aan de rechtspositie van Nationale-Nederlanden. Dit kan anders zijn in een geval als aan de orde in het Trafigura-arrest: de verweren van Trafigura kunnen verschillen al naar gelang de Stichting optreedt als (directe of indirecte) vertegenwoordiger van de belanghebbenden, dan wel als collectieve belangenbehartiger in de zin van art. 3:305a BW (oud); dit geldt eens te meer wat betreft het optreden als belangenbehartiger op grond van art. 3:305a BW, zoals dat ingevolge de WAMCA luidt, versus optreden als (directe of indirecte) vertegenwoordiger van een groep belanghebbenden. ${ }^{58}$ Terecht kent de Hoge Raad wat ons betreft voor het al dan niet toestaan van een uitzondering dan ook betekenis toe aan vooral de omstandigheid dat er sprake was van een verandering van hoedanigheid in een zeer vroeg stadium van de procedure, alsook aan de omstandigheid dat Trafigura hierdoor blijkbaar niet werd verrast. Het verdedigingsbelang is echter niet het enige belang dat naar ons oordeel gewicht in de schaal legt bij de beoordeling van de vraag of er een rechtvaardiging bestaat om het verbod van verandering van partijhoedanigheid in de desbetreffende zaak terzijde te stellen.

Een wijziging van partijhoedanigheid moet naar onze mening worden geweigerd als deze wijziging de procedure te veel vertraagt. Wij refereren in dit verband aan hetgeen over deformalisering is opgemerkt in 'Snijders, Klaassen \& Meijer': dit maakt het proces eenvoudiger, in die zin dat formalistische barrières voor werkelijke rechtsverwezenlijking worden opgeruimd, maar paradoxaal genoeg kan dit tegelijkertijd het procederen er niet gemakkelijker op maken omdat deformaliserende correctiemogelijkheden op zichzelf ook procedurele complicaties vormen, die geld en tijd kunnen kosten. ${ }^{59} \mathrm{~W}_{\mathrm{ij}}$ menen dat de eisen van een goede procesorde uiteindelijk bepalend dienen te zijn voor de toelaatbaarheid van een hoedanigheidswissel. ${ }^{60}$ Enigszins opmerkelijk is dat de Hoge Raad slechts de goede procesorde noemt als basis van het uitgangspunt dat een wijziging van partijhoedanigheid niet is toegestaan. ${ }^{61} \mathrm{Wij}$ zouden menen dat dit uitgangspunt zijn grondslag vooral of althans tevens vindt in de rechtszekerheid, en de goede procesorde de rechtvaardiging kan vormen voor de eventuele afwijking hiervan. ${ }^{62}$ De goede procesorde is weliswaar een open norm en de uitkomst hiervan is niet in steen gebeiteld, maar in combinatie met de klassieke beginselen van ons procesrecht, zoals het beginsel van hoor en weder-

58. In het bijzonder kan in dit verband worden gedacht aan de aangescherpte ontvankelijkheidsvereisten voor belangenorganisaties, die grond kunnen vormen voor verweer van de gedaagde.

59. Snijders, Klaassen \& Meijer 2017/38.

60. Vgl. ook A. Knigge, 'Deformalisering, benadeling en partijperikelen', in: R.J.C. Flach e.a. (red.), Amice. Rutgers-bundel, Deventer: Kluwer 2005 , p. $187-196$

61. Zie HR 3 april 2020, ECLI:NL:HR:2020:587 (Trafigura), r.o. 3.2.

62. Dit is anders bij de wijziging van eis alsook voeging en tussenkomst, waar de goede procesorde volledig bepalend is. Het verschil is echter dat de wet in de bevoegdheid tot het wijzigen van eis alsook voegen en tussenkomen voorziet, terwijl voor de mogelijkheid tot het wisselen van partijhoedanigheid een wettelijke grondslag ontbreekt. hoor, geeft dit naar ons oordeel toch voldoende richting en houvast aan de rechtspraktijk. ${ }^{63}$

\section{De gevolgde en de te volgen route; een tweetal observaties}

De rechtspraak betreffende de wijziging van partijhoedanigheid c.q. de (on)toelaatbaarheid hiervan onder de loep nemend, vallen (verder) de volgende twee punten op wat betreft de benadering die wordt gevolgd.

Allereerst springt in het oog dat A-G De Bock meent dat (vooral) omdat Trafigura bij aanvang van de procedure al rekening hield met de hoedanigheid van de Stichting als belangenbehartiger überhaupt geen sprake was van een wijziging van partijhoedanigheid. Zij kent aan deze omstandigheid derhalve betekenis toe in het kader van de uitleg van de dagvaarding. ${ }^{64}$ De Hoge Raad komt niet toe aan de beoordeling van de klacht over de uitleg van de dagvaarding. De omstandigheid dat Trafigura kennelijk bij aanvang van de procedure al rekening hield met de mogelijkheid dat de Stichting ook optrad in de hoedanigheid van belangenbehartiger, speelt volgens de motivering van de Hoge Raad evenwel een rol bij het buiten toepassing laten van het uitgangspunt dat een wijziging van partijhoedanigheid niet is toegestaan. De vraag rijst of het vertrouwen bij de wederpartij op een bepaalde hoedanigheid (inderdaad) een rol kan spelen bij de vraag of sprake is van een wijziging van partijhoedanigheid én bij het al dan niet aannemen van een uitzondering daarop. Wij zijn geneigd te menen dat de hoedanigheid van eiser waarmee de gedaagde rekening hield een aspect is waaraan in zijn algemeenheid (slechts) betekenis toekomt bij de beantwoording van de vraag wie partij is, en dus bij de uitleg die met inachtneming van de wilsvertrouwensleer aan de dagvaarding wordt gegeven. Indien de uitkomst hiervan is dat de eiser in de dagvaarding in een andere hoedanigheid is opgetreden dan hij gaande de procedure pretendeert, lijkt er geen ruimte om bij de beoordeling van de vraag of deze verandering bij wijze van uitzondering toegelaten moet worden, zelfstandige betekenis toe te kennen aan ditzelfde vertrouwen, althans lijkt dit niet ten gunste van een dergelijke uitzondering te kunnen uitpakken. De omstandigheid dat het aannemen van de nieuwe hoedanigheid in het desbetreffende geval niet als een verrassing komt, zou eventueel wel een relevant gezichtspunt kunnen zijn in het kader van de toets aan de 'goede procesorde' (in het licht van de toets of gedaagde in zijn verdedigingsbelang is geschaad), maar dit is iets anders.

Een tweede observatie is dat in de hiervoor besproken rechtspraak soms een vrij grote mate van flexibiliteit wordt betracht bij de beoordeling van de hoedanigheid waarin wordt geprocedeerd; althans wordt, anders gezegd, terughoudend-

63. Vgl. Snijders, Klaassen en Meijer 2017/54.

64. Zie concl. A-G onder 4.50 e.v., met name onder 4.54-4.56. Zie voor de regels voor het vaststellen van een partijhoedanigheid HR 22 oktober 2004, ECLI:NL:HR:2004:AP1435, NJ 2006/202, m.nt. H.J. Snijders, $J B P r 2005 / 5$, m.nt. A. Knigge en L.C. Dufour (X/ABN AMRO Bank), r.o. 3.4. 
heid betracht bij het aannemen dat er sprake is van een hoedanigheidswissel. In andere gevallen lijkt de Hoge Raad wat strikter te zijn bij de duiding van de hoedanigheid waarin is en wordt geprocedeerd, maar wordt flexibiliteit getoond wat betreft de toelaatbaarheid van een hoedanigheidswissel. De arresten NVPI/Snelleman en Coopag/ABN AMRO Bank kunnen in de eerste categorie worden geplaatst, de arresten Van Kessel/Nationale-Nederlanden en Trafigura in de tweede categorie. Een strikt onderscheid tussen de vraag óf er sprake is van een hoedanigheidswissel en de vraag of deze in het voorliggende geval (on)toelaatbaar is, is in de praktijk wellicht ook niet steeds te maken. In elk geval in hoger beroep en cassatie kan het oordeel immers mede worden bepaald door de wijze waarop de rechtsmiddelen zijn ingekleed. Niettemin komt het ons nuttig voor deze kwesties wel zo veel als mogelijk te scheiden, niet in de laatste plaats omdat de beoordelingscriteria verschillen en de rechter bij de beantwoording van de ene vraag meer beoordelingsruimte toekomt dan bij de andere, althans in onze benadering (zie par. 6 hierna).

\section{Slotopmerkingen en conclusie}

Duidelijkheid over de identiteit en de hoedanigheid van de eisende partij is van groot belang. Wie optreedt als eisende partij wordt in principe bepaald door uitleg van de dagvaarding. Een wijziging van partijhoedanigheid gaande de procedure is in beginsel verboden. Of sprake is van een wijziging van partijhoedanigheid wordt door de Hoge Raad op twee verschillende manieren getoetst. De eerste benadering is dat wordt beoordeeld of de persoon van de materiële procespartij verandert. De tweede benadering is dat beslissend is of een procespartij in eigen naam blijft procederen. Opmerkelijk genoeg kunnen die benaderingen in concrete gevallen tegengestelde conclusies opleveren. Wij noemden als voorbeeld de eiser die gedurende het geding opmerkt dat hij zijn vordering niet langer voor zichzelf instelt, maar als lasthebber in eigen naam voor een derde. In die situatie treedt een verandering van de materiële procespartij op, maar blijft eiser wel in eigen naam procederen. De Hoge Raad acht in deze situatie, althans in het arrest $X /$ Euretco, een wijziging van partijhoedanigheid niet aan de orde; volgens de redenering van het Trafiguraarrest zou er echter wél sprake zijn van een hoedanigheidswissel. Voor een helder begrip van het leerstuk van de verboden wijziging van partijhoedanigheid en met name voor de rechtszekerheid verdient het naar onze mening aanbeveling dat het leerstuk in alle gevallen op een consistente manier wordt toegepast. In navolging van A-G De Bock in de conclusie voor het Trafigura-arrest zouden wij voor het antwoord op de vraag of er sprake is van een hoedanigheidswissel bepalend willen laten zijn of er sprake is van een verschuiving in het optreden als formele dan wel materiële procespartij. Deze insteek biedt naar onze mening de meeste duidelijkheid.

Een wijziging van partijhoedanigheid hoeft niet verboden te zijn. Zoals uit de rechtspraak blijkt, is er ook op dit terrein sprake van deformalisering. Dit is wat ons betreft op zichzelf toe te juichen. Niettemin lijkt wat meer duidelijkheid over de maatstaf die in dit kader richting geeft wenselijk. Wat ons betreft dient voor het antwoord op de vraag of een verandering van partijhoedanigheid in concreto moet worden toegestaan de goede procesorde richtinggevend te zijn. In het bijzonder dient hierbij te worden meegewogen of er sprake is van schending van het verdedigingsbelang en/of een (ontoelaatbare) vertraging van de procedure. 